\title{
ANALISIS PENGARUH TEMPAT PENYIMPANAN TERHADAP BESARNYA KANDUNGAN LOGAM Pb DAN Zn DALAM DAGING KORNET HABIS PAKAI KEMASAN KALENG
}

\author{
Syamsuri Syakri, A.Mumtihanah Mursyid
}

Fakultas Farmasi Universitas Muslim Indonesia

Email : surisweet86@yahoo.com

\begin{abstract}
This research was conducted with the aim to investigate the influence of storage on the size of the metal content of $\mathrm{Pb}$ and $\mathrm{Zn}$ to quality consumable products corned beef cans obtained from a grocery store or supermarket, and to determine the ratio between the metals $\mathrm{Pb}$ and $\mathrm{Zn}$ results, with SK. DG BPOM No.03725/ B / SK / VII / 89 maximum of metal contamination in food. In this study, the sampling method used is the method of random sampling in which sampling method from a single population and each population has an equal chance to be selected as sample. Analysis of heavy metal $\mathrm{Pb}$ in all samples showed uptake results ranged from 0.0000 to 0.0005 , or may be heavy metal pollution $P b$ is very small. Total $P b$ (lead) was much less after storage in the refrigerator for 1 day of corned beef packaging consumables, it is possible the influence of the storage temperature. Analysis of $Z n$ metal in the samples showed varying results, it is because the meat itself was contained zinc metal content. Total Zn (Zinc) also was less after storage in the refrigerator for 1 day of corned beef packaging consumables, it is possible the influence of storage temperature affect the metal content. Analysis of $\mathrm{Pb}$ (lead) and $\mathrm{Zn}$ (zinc) in a sample of corned beef canned consumables still below the threshold set by decree. SNI No. 7387:2009 above the maximum limit of metal contamination in food, so the packaging corned beef is still suitable for consumption and circulated in the market.
\end{abstract}

Key words: Corned Meat Packaging Cans, Metal Pb, Zn Metal, Storage

\section{PENDAHULUAN}

Daging sapi merupakan salah satu jenis daging yang di konsumsi oleh manusia, misalnya daging sapi dalam kaleng. Akan tetapi masyarakat belum tahu berapa besar kontaminasi logam berat dalam makanan tersebut. Data mengenai kontaminasi logam berat dalam makanan masih sedikit, oleh karena itu data kandungan logam berat dari hasil penelitian ini mungkin dapat digunakan sebagai informasi bagi instansi yang berwenang mengenai masalah tersebut ( Suwirna. S., dkk, 1981).

Daging kornet semakin menjadi pilihan bagi banyak orang. Produk olahan daging ini juga cepat dan mudah diolah. Sebagai makanan yang digemari masyarakat, corned beef ada 
kemungkinan mengandung logamlogam berbahaya seperti seng dan timbal, dan kaleng yang tersusun dari logam $\mathrm{Sn}$, Fe dan $\mathrm{Pb}$ mempunyai daya tahan terhadap korosi terbatas. Logam-logam tersebut mudah bereaksi dengan asam sehingga pada keasaman $(\mathrm{pH})$ tertentu dan lama penyimpanan yang tertentu pula, akan terjadi pencemaran terhadap corned beef. Logam berat merupakan komponen alami tanah. Elemen ini tidak dapat didegradasi maupun dihancurkan. Logam berat dapat masuk ke dalam tubuh manusia lewat makanan, air minum, atau melalui udara. Logam-logam berat seperti seng dibutuhkan tubuh manusia untuk membantu kinerja metabolisme tubuh. Logam-logam tersebut berpotensi menjadi racun jika konsentrasi dalam tubuh tinggi. Logam berat menjadi berbahaya disebabkan sistem bioakumulasi. Bioakumulasi berarti peningkatan konsentrasi unsur kimia tersebut dalam tubuh makhluk hidup sesuai piramida makanan. Akumulasi atau peningkatan konsentrasi logam berat di alam mengakibatkan konsentrasi logam berat di tubuh manusia adalah tertinggi. Jumlah yang terakumulasi setara dengan jumlah logam berat yang tersimpan dalam tubuh di tambah jumlah yang di ambil dari makanan, minuman, atau udara yang terhirup. Jumlah logam berat yang terakumulasi lebih cepat dibandingkan dengan jumlah yang terekskresi dan terdegradasi.

Makanan yang tinggi kadar timbalnya antara lain makanan yang dikemas dalam kaleng, kerangkerangan dan sayur-sayuran yang ditanam di dekat jalan raya. Akibat pencemaran timbal dan kadmium pada lingkungan dapat menyebabkan makanan yang kita konsumsi, air yang kita minum dan udara yang kita hirup kemungkinan telah terkontaminasi dengan timbal dan kadmium. Residu logam-logam berat di dalam tubuh bersifat kumulatif dan dapat mengganggu sistem darah dan urat syaraf serta kerja ginjal. (Supriyanto.C.,dkk, 1999).

\section{METODE PENELITIAN}

\section{A. Tempat dan Waktu}

Penelitian ini dilaksanakan di Balai Besar Laboratorium Kesehatan Makassar, sejak tanggal 25 agustus sampai 8 september 2011.

B. Alat dan Bahan

Adapun alat yang digunakan Atomic Absorption Spectrophotometry Perkin-Elmer 5100PC, Atomic Absorption Spectrophotometry Perkin-Elmer 
3100PC, cawan porselen, hot plate, kertas Saring Whatman 42, neraca analitik, peralatan gelas laboratorium

Adapun bahan yang digunakan Aquabidestillata, aquadest, larutan standar $\mathrm{Pb}$ merek Spektrosol, larutan standar Zn merek Spektrosol, larutan Asam Nitrat $\left(\mathrm{HNO}_{3}\right)$ pekat, sampel : Daging kornet (Corned beef) habis pakai kemasan kaleng

\section{Prosedur Penelitian}

\section{a. Metode Sampling}

Pada penelitian ini
metode sampling yang
digunakan yaitu metode
sampling random dimana cara
pengambilan sampel dari satu
populasi dan setiap populasi
memiliki kesempatan yang
sama untuk dipilih sebagai
sampel.

\section{Populasi Sasaran}

Populasi yang di pilih adalah daging sapi kornet kemasan kaleng yang di beli dari Toko kelontongan atau supermarket dengan merek " $x$ " dan " $y$ ", kemudian isi daging sapi kornet digunakan dan sisanya disimpan dalam lemari es.
2. Variabel

Pada penelitian ini variabel yang di ambil adalah :
a. Tempat Penyimpanan Sampel
b. Lama Penyimpanan masing-masing sampel di lemari es

\section{Batasan Masalah}

Dalam penelitian ini batasan masalahnya pada analisis kandungan logam timbal dan seng dalam sampel daging sapi korned yang di beli pada toko kelontong atau supermarket yang ada di Makassar dan analisis dengan menggunakan alat Spektrofotometri Serapan Atom (Mustafa, 2000).

\section{b. Jenis Sampel}

Sampel yang dipakai adalah daging korned yang dikemas dalam kaleng, sampel di ambil secara acak pada toko kelontongan atau supermarket yang ada di Makassar dengan mnegukur kandungan $\mathrm{Pb}$ dan Zn pada masing-masing sampel sebelum dan sesudah penyimpanan di lemari es. 
Sampel yang di beli di Toko kelontongan atau supermarket :

a) Sampel $A_{1}$ : Daging kornet kemasan merek " $x$ "sebelum penyimpanan di lemari es.

b) Sampel $A_{2}$ : Daging kornet kemasan habis pakai merek " $x$ " yang disimpan di lemari es selama 1 hari

c) Sampel $B_{1}$ : Daging kornet kemasan merek "y"sebelum penyimpanan di lemari es

d) Sampel $B_{2}$ : Daging kornet kemasan habis pakai merek "y" yang disimpan di lemari es selama 1 hari

\section{c. Pembuatan Larutan}

\section{Pembuatan}

Larutan

\section{Standar $\mathbf{P b}$}

Larutan standar $\mathrm{Pb}$ induk $1000 \mathrm{mg} / \mathrm{L}$ dibuat dari larutan dengan merek dagang spektrosol. Larutan $\mathrm{Pb} 50 \mathrm{mg} / \mathrm{L}$ dibuat dengan cara memindahkan $0,5 \mathrm{ml}$ larutan baku 1000 mg/L ke dalam labu ukur $50 \mathrm{ml}$ kemudian diencerkan sampai batas. Larutan standar 0,2 mg/L, 0,4 mg/L, 0,6 mg/L, 0,8 mg/L dan 1,0 $\mathrm{mg} / \mathrm{L}$ dibuat dengan cara memindahkan 0,5 ml; $1 \mathrm{ml}$;
$2 \mathrm{ml} ; 3 \mathrm{ml}$ dan $4 \mathrm{ml}$ larutan baku $50 \mathrm{mg} / \mathrm{L}$ ke dalam labu ukur $50 \mathrm{ml}$ kemudian diencerkan sampai batas.

2. Pembuatan

Larutan Standar Zn

Larutan standar Zn induk $1000 \mathrm{mg} / \mathrm{L}$ dibuat dari larutan dengan merek dagang spektrosol. Larutan Zn 50 mg/L dibuat dengan cara memindahkan $0,5 \mathrm{ml}$ larutan baku 1000 mg/L ke dalam labu ukur $50 \mathrm{ml}$ kemudian diencerkan sampai batas. Larutan standar 1,0 mg/L, 2,0 mg/L, $3,0 \mathrm{mg} / \mathrm{L}, 4,0 \mathrm{mg} / \mathrm{L}$ dan 5,0 $\mathrm{mg} / \mathrm{L}$ dibuat dengan cara memindahkan $1 \mathrm{ml} ; 2 \mathrm{ml} ; 3$ $\mathrm{ml} ; 4 \mathrm{ml}$ dan $5 \mathrm{ml}$ larutan baku 50 mg/L ke dalam labu ukur $50 \mathrm{ml}$ kemudian diencerkan sampai batas.

Larutan standar $\mathrm{Zn}$ dibuat dengan cara pengenceran dari larutan induk 1000 mg/L dengan rumus sebagai berikut :

$$
V_{1} \times M_{1}=V_{2} \times M_{2}
$$

\section{d. Preparasi Sampel}

Ditimbang dengan tepat masing-masing sebanyak $10 \mathrm{~g}$ sampel corned beef merek " $x$ " 
dan "y" dan dimasukkan ke dalam gelas beker $250 \mathrm{ml}$, kemudian ditambah dengan 20 $\mathrm{ml}$ aquades dan $5 \mathrm{ml} \mathrm{HNO}_{3}$. Larutan dipanaskan selama 1 menit pada hot plate atau sampai sampel menguap. Kemudian di dinginkan. Saring dengan kertas saring Whathman 42 kemudian larutan dipindahkan ke dalam labu ukur $50 \mathrm{ml}$ setelah itu ditambahkan aquades hingga volumenya tepat $50 \mathrm{ml}$, kemudian dianalisis dengan SSA (S. James, 1999). Ulangi perlakuan tersebut dengan menggunakan corned beef habis pakai yang disimpan di lemari es selama 1-2 hari.

\section{e. Pembuatan Kurva Standar}

Diambil larutan standar $\mathrm{Pb}$ dan $\mathrm{Zn}$ dengan masingmasing konsentrasi, lalu pada masing-masing larutan standar tersebut diamati absorbansinya $\mathrm{Pb}$ pada panjang gelombang 283,3 nm dan Zn pada panjang gelombang 213,9 $\mathrm{nm}$. Kemudian dari data yang diperoleh dibuat ke dalam bentuk kurva hubungan antara konsentrasi $(\mathrm{C}) \mathrm{Pb}$ standar dan $\mathrm{Zn} \quad$ standar dengan absorbansinya (A) sehingga diperoleh kurva standar berupa garis lurus.

\section{HASIL PENELITIAN}

Tabel 1. Analisis Kandungan Pb (Timbal) Sebelum Penyimpanan Di Lemari Es

\begin{tabular}{cccccc}
\hline No. & Sampel & Berat $(\mathbf{g})$ & Absorban & Konsentrasi $(\mathbf{p p m})$ & Kandungan $\mathbf{P b}(\boldsymbol{\mu g} \mathbf{g} \mathbf{g})$ \\
\hline 1. & Sampel $\mathrm{A}_{1.1}$ & 10 & 0,0022 & 0,0516 & 0,258 \\
2. & Sampel $\mathrm{A}_{1.2}$ & 10 & 0,0020 & 0,0470 & 0,235 \\
3. & Sampel $\mathrm{B}_{1.1}$ & 10 & 0,0015 & 0,0363 & 0,1815 \\
4. & Sampel $\mathrm{B}_{1.2}$ & 10 & 0,0018 & 0,0416 & 0,208 \\
\hline
\end{tabular}

Tabel 2. Analisis Kandungan $\mathrm{Pb}$ (Timbal) Setelah Penyimpanan Di Lemari Es Selama 1 Hari

\begin{tabular}{cccccc}
\hline No. & Sampel & Berat $(\mathbf{g})$ & Absorban & Konsentrasi $(\mathbf{p p m})$ & Kandungan $\mathbf{P b}(\boldsymbol{\mu g} \mathbf{g} \mathbf{g})$ \\
\hline 1. & Sampel $\mathrm{A}_{2.1}$ & 10 & 0,0019 & 0,0456 & 0,228 \\
2. & Sampel $\mathrm{A}_{2.2}$ & 10 & 0,0017 & 0,0398 & 0,199 \\
3. & Sampel $\mathrm{B}_{2.1}$ & 10 & 0,0039 & 0,0906 & 0,453 \\
4. & Sampel $\mathrm{B}_{2.2}$ & 10 & 0,0038 & 0,0895 & 0,4475 \\
\hline
\end{tabular}


Tabel 3. Analisis Kandungan Zn (Seng) Sebelum Penyimpanan Di Lemari Es

\begin{tabular}{cccccc}
\hline No. & Sampel & Berat $\mathbf{( g )}$ & Absorban & Konsentrasi $(\mathbf{p p m})$ & Kandungan $\mathbf{P b}(\boldsymbol{\mu g} \mathbf{g} \mathbf{g})$ \\
\hline 1. & Sampel $\mathrm{A}_{1.1}$ & 10 & 0,4080 & 3,1922 & 15,961 \\
2. & Sampel $\mathrm{A}_{1.2}$ & 10 & 0,4025 & 3,1486 & 15,743 \\
3. & Sampel $\mathrm{B}_{1.1}$ & 10 & 0,2804 & 2,1935 & 10,9675 \\
4. & Sampel $\mathrm{B}_{1.2}$ & 10 & 0,2839 & 2,2213 & 11,1065 \\
\hline
\end{tabular}

Tabel 4. Analisis Kandungan Zn (Seng) Setelah Penyimpanan Di Lemari Es Selama 1 Hari

\begin{tabular}{cccccc}
\hline No. & Sampel & Berat $(\mathbf{g})$ & Absorban & Konsentrasi $(\mathbf{p p m})$ & Kandungan $\mathbf{P b}(\boldsymbol{\mu g} \mathbf{g} \mathbf{g})$ \\
\hline 1. & Sampel $\mathrm{A}_{2.1}$ & 10 & 0,3644 & 2,8509 & 14,2545 \\
2. & Sampel $\mathrm{A}_{2.2}$ & 10 & 0,3559 & 2,7840 & 13,92 \\
3. & Sampel $\mathrm{B}_{2.1}$ & 10 & 0,2091 & 1,6362 & 8,181 \\
4. & Sampel $\mathrm{B}_{2.2}$ & 10 & 0,2180 & 1,7058 & 8,529 \\
\hline
\end{tabular}

\section{PEMBAHASAN}

Pada penentuan kandungan logam $\mathrm{Pb}$ (Timbal) dan $\mathrm{Zn}$ (Seng) dalam corned beef dilakukan pada panjang gelombang untuk $\mathrm{Pb} 283,3$ $\mathrm{nm}$ dan $\mathrm{Zn}$ 213,9 nm. Panjang gelombang ini merupakan panjang gelombang optimum untuk logam $\mathrm{Pb}$ dan $\mathrm{Zn}$ yang paling kuat menyerap garis untuk transisi elektronik dari tingkat dasar ketingkat eksitasi karena pada panjang gelombang memiliki energi yang besar yaitu $\mathrm{Pb} 7,0134.10$ ${ }^{19}$ joule dan untuk $\mathrm{Zn}$ 9,2889.10-19 joule.

Larutan standar $\mathrm{Pb}$ di buat dengan konsentrasi $0,0 \mathrm{mg} / \mathrm{L} ; 0,2 \mathrm{mg} / \mathrm{L} ; 0,4$ $\mathrm{mg} / \mathrm{L} ; 0,6 \mathrm{mg} / \mathrm{L} ; 0,8 \mathrm{mg} / \mathrm{L}$ dan $1,0 \mathrm{mg} / \mathrm{L}$ dari larutan induk Pb 1000 mg/L yaitu dengan cara pengenceran. Untuk perhitungan selanjutnya disajikan pada lampiran 2. Kemudian masing-masing konsentrasi larutan standar $\mathrm{Pb}$ dianalisis dengan spektrofotometri serapan atom, dari absorbansi yang diperoleh kemudian dibuat kurva kalibrasi yang merupakan garis lurus antara konsentrasi versus absorbansi. Absorbansi menunjukkan kemampuan sampel untuk menyerap radiasi elektromagnetik pada panjang gelombang maksimum. Data hasil pengukuran larutan standar $\mathrm{Pb}$ disajikan pada tabel dibawah ini :

\begin{tabular}{ccc}
\hline No. & Konsentrasi (mg/L) & Absorbansi \\
\hline 1. & 0 & $-0,0009$ \\
2. & 0,2 & 0,0079 \\
3. & 0,4 & 0,0173 \\
4. & 0,6 & 0,0259 \\
5. & 0,8 & 0,0343 \\
6 & 1,0 & 0,0424 \\
\hline
\end{tabular}

maka dapat dibuat kurva kalibrasi konsentrasi versus absorbansi. Dari hasil pengukuran didapat kurva kalibrasi standar linier, kurva kalibrasi ini nantinya digunakan untuk menentukan konsentrasi sampel yang terukur sebenarnya dengan menggunakan persamaan regresi linier yaitu $Y=b x+a$. 
Larutan standar $\mathrm{Zn}$ di buat dengan konsentrasi $0,0 \mathrm{mg} / \mathrm{L} ; 1,0$ $\mathrm{mg} / \mathrm{L} ; 2,0 \mathrm{mg} / \mathrm{L} ; 3,0 \mathrm{mg} / \mathrm{L} ; 4,0 \mathrm{mg} / \mathrm{L}$ dan $5,0 \mathrm{mg} / \mathrm{L}$ dari larutan induk $\mathrm{Zn}$ $1000 \mathrm{mg} / \mathrm{L}$ yaitu dengan cara pengenceran. Kemudian masingmasing konsentrasi larutan standar $\mathrm{Zn}$ dianalisis dengan spektrofotometri serapan atom, dari absorbansi yang diperoleh kemudian dibuat kurva kalibrasi yang merupakan garis lurus antara konsentrasi versus absorbansi. Absorbansi menunjukkan kemampuan sampel untuk menyerap radiasi elektromagnetik pada panjang gelombang maksimum. Data hasil pengukuran larutan standar $\mathrm{Zn}$ disajikan pada tabel berikut ini :

\begin{tabular}{ccc}
\hline No. & Konsentrasi (mg/L) & Absorbansi \\
\hline 1. & 0 & $-0,0007$ \\
2. & 1,0 & 0,1417 \\
3. & 2,0 & 0,2606 \\
4. & 3,0 & 0,3883 \\
5. & 4,0 & 0,4961 \\
6 & 5,0 & 0,6437 \\
\hline
\end{tabular}

metode Spektrofotometri Serapan Atom (SSA) untuk mengetahui kadar logam berat $\mathrm{Pb}$ (timbal) dan $\mathrm{Zn}$ (Seng) yang terkandung dalam dalam sampel daging kornet kemasan sebelum dan sesudah penyimpanan di lemari es. Adanya logam berat dalam daging kaleng sangat berbahaya bagi manusia, apalagi keberadaan logam berat yang berlebih dalam makanan sudah dilarang oleh pemerintah karena sangat berbahaya bagi kesehatan manusia baik dalam jangka pendek maupun jangka panjang. Keberadaan logam $\mathrm{Pb}$ dan $\mathrm{Zn}$ mungkin akibat korosi yang dapat terjadi pada kaleng. Sedangkan bahan-bahan yang menyebabkan korosi adalah bahan yang terdiri dari asam, basa, serta garam baik dalam bentuk senyawa anorganik maupun organik. Faktor yang berpengaruh terhadap korosi dapat dibedakan menjadi dua, yaitu yang berasal dari bahan itu sendiri dan dari lingkungan. Faktor dari bahan adalah kemurnian bahan, teknik pencampuran bahan dan sebagainya. Sedangkan beberapa faktor yang menentukan besarnya korosi pada kaleng bagian dalam adalah $\mathrm{pH}$ makanan dalam kaleng, tingginya sisa oksigen dalam makanan, jenis kaleng dan jenis lapisan penahan korosi, suhu dan lama penyimpanan. Sedangkan besarnya korosi pada bagian luar ditentukan antara lain oleh jenis kaleng dan tipisnya lapisan timah.

Pada Analisis dengan spektrofotometri serapan atom memerlukan sampel dalam bentuk larutan. Oleh karena itu, sampelsampel organik harus didestruksi terlebih dahulu, daging kornet kemasan kaleng merupakan sampel 
organik. Diharapkan dengan melakukan destruksi yang tertinggal hanya logam-logamnya saja. Proses ini sangat penting karena akan sangat menentukan berhasil atau tidaknya analisis.

Sampel yang digunakan pada penelitian ini adalah daging kornet kemasan kaleng yang merupakan sampel organik, sehingga untuk dapat menentukan kandungan logam timbal dan seng yang ada dalam daging kornet kemasan kaleng tersebut perlu dilakukan destruksi terlebih dahulu. Destruksi yang dilakukan adalah destruksi basah, dengan destruktor $\mathrm{HNO}_{3}$ pekat, karena $\mathrm{HNO}_{3}$ dapat digunakan untuk menghancurkan bahan-bahan organik. Dengan menggunakan destruksi ini diharapkan agar hasil yang diperoleh maksimal, proses destruksi ini perlu dilakukan dengan hati-hati karena kesalahan metode analisis sangat berhubungan dengan proses destruksi sampel dan optimasi alat SSA. Pada penentuan logam $\mathrm{Pb}$ dan $\mathrm{Zn}$ dalam sampel daging kornet kemasan dengan menggunakan SSA nyala, yaitu udara sebagai oksidan dan asetilen sebagai bahan bakar. Larutan sampel dilewatkan pada nyala sehingga terbentuk uap atom yang akan dianalisis dan akan menyerap radiasi sinar yang dihasilkan $\mathrm{HCL}$, sinar akan melalui monokromator untuk memilih panjang gelombang kemudian masuk dalam detektor dan absorbansi sampel akan terbaca dalam sistem pembacaan alat.

Kondisi yang ideal untuk suatu analisis mengunakan metode nyala SSA adalah larutan sampel yang dianalisis harus memenuhi ketentuan bahwa larutan sampel harus berada dalam matrik yang identik dengan larutan standar. Dari hasil penelitian didapatkan data absorbansi dan konsentrasi sampel, kemudian hasil Absorbansi yang didapat dari masingmasing parameter dimasukkan ke dalam kurva kalibrasi larutan standar $\mathrm{Pb}$ dan $\mathrm{Zn}$ maka didapatkan kadar $\mathrm{Pb}$ dan $\mathrm{Zn}$ dalam kurva kalibrasi dengan satuan $\mathrm{mg} / \mathrm{L}$.

Analisis logam berat $\mathrm{Pb}$ dalam seluruh sampel menunjukkan hasil serapan yang berkisar antara 0,0000 0,0005 atau dapat dikatakan pencemaran logam berat $\mathrm{Pb}$ sangat kecil. Kecilnya kandungan logam $\mathrm{Pb}$ yang terdapat dalam daging kornet kemasan dan masih dibawah batas ambang yang telah ditetapkan oleh SNI Nomor 7387:2009 yaitu 2,0 $\mu \mathrm{g} / \mathrm{g}$ kemungkinan ditimbulkan dari solder pada bagian sambungan badan kaleng (soldered side seam) dan sedikitnya 
kandungan logam yang terdapat pada daging kornet kemasan tidak lepas dari sempurnanya proses penyambungan itu sendiri. Bagian dalam kaleng yang sudah dibersihkan tidak memperlihatkan adanya bekas cipratan mengelembung. Secara keseluruhan kaleng pengemas sampel yang diteliti memiliki solderan yang baik, rata dan rapih. Hal inilah yang menyebabkan sampel terbebas dari kontaminasi logam berat $\mathrm{Pb}$ yang berlebih. Sampel yang dibeli pada toko kelontongan dan supermarket tidak terdapat peningkatan kadar yang signifikan, ini berarti bahwa tidak adanya pengaruh penyimpanan terhadap besarnya kadar logam $\mathrm{Pb}$ yang ada pada daging kornet kemasan.

Meskipun hasil penelitian kandungan logam berat $\mathrm{Pb}$ masih dibawah batas ambang yang ditetapkan oleh SNI Nomor 7387:2009 tetapi perlu diwaspadai bahwa logam $\mathrm{Pb}$ dapat terakumulasi dalam tubuh manusia karena tubuh manusia tidak membutuhkan logam $\mathrm{Pb}$.

Jumlah $\mathrm{Pb}$ (timbal) ternyata lebih sedikit sesudah penyimpanan di lemari es selama 1 hari dari kemasan daging kornet habis pakai, ini dimungkinkan adanya pengaruh suhu penyimpanan.
Analisis logam $\mathrm{Zn}$ dalam sampel menunjukkan hasil yang bervariasi, ini disebabkan karena dalam daging itu sendiri sudah terdapat kandungan logam Zn. Karena manusia membutuhkan sekitar 2 gram seng perharinya, dalam tubuh manusia seng sangat essensial bagi enzim, selain itu seng berfungsi membantu pertumbuhan, seng juga membantu dalam penyembuhan luka dan diperkirakan seng diperlukan juga untuk mobilisasi vitamin A dari tempat penyimpanan hati. Walaupun seng diperlukan oleh tubuh manusia, kelebihan seng juga dapat menyebabkan gangguan kesehatan. batas ambang yang telah ditetapkan oleh SNI Nomor 7387:2009 yaitu 40 $\mu \mathrm{g} / \mathrm{g}$.

Jumlah Zn (Seng) juga ternyata lebih sedikit sesudah penyimpanan di lemari es selama 1 hari dari kemasan daging kornet habis pakai, ini dimungkinkan adanya pengaruh suhu penyimpanan yang berpengruh terhadap kandungan logam.

\section{KESIMPULAN}

1. Hasil analisis logam berat $\mathrm{Pb}$ dan $\mathrm{Zn}$ dalam sampel daging kornet habis pakai kemasan kaleng yang dibeli pada toko kelontongan atau supermarket menunjukkan bahwa 
ada pengaruh pada tempat penyimpanannya.

2. Kandungan Logam $\mathrm{Pb}$ (timbal) dan Zn (seng) yang dimiliki daging kornet habis pakai kemasan kaleng ternyata lebih sedikit jika dimasukkan ke dalam lemari es, dibandingkan pada saat daging korned kemasan kaleng masih dalam keadaan utuh.

3. Analisis $\mathrm{Pb}$ (timbal) dan $\mathrm{Zn}$ (seng) pada sampel daging kornet habis pakai kemasan kaleng masih di bawah batas ambang yang ditetapkan oleh SNI Nomor 7387:2009 tentang batas maksimum cemaran logam dalam makanan, sehingga daging kornet kemasan ini masih layak untuk dikonsumsi dan diedarkan dipasaran.

\section{DAFTAR PUSTAKA}

Anonim,2007, American Journal of Clinical Nutrition, http://www.info-sehat.

Com/content.php?s_sid=1012

Darmono. 1995. Logam Dalam Sistem Biologi Makhluk Hidup. Universitas Indonesia Press. Jaakarta. 75, 76, 89, 122.

DR.P.V Chadha, Timbal, IImu Forensik dan Toksikologi., Edisi 5, PenerbitWidya Medika., Jakarta, 1995, 268 - 272.

Homan CS, Brogan GX, Lead Toxicity, in : Viccellio $P$, (Editor ).,
Handbook of Medical Toxicology, First edition, Little, Brown and Co. Boston., 1993, $271-284$.

lets-belajar.blogspot.com/2007., 2007., Logam Berat., diakses 01-122010.

Mejare, M dan L . Bullow., 2001., Metal Binding Proteins And Peptides In Bioremediation And Phytoremediation Of Heavy Metals.,Trends In Biotekhnology 19 (2) ; 67-73.

Palar, H. 1994., Pencemaran dan Toksikologi Logam Berat., Penerbit Rineka Cipta., Jakarta.

Sacharow, S. R.C. Griffin. 1970. Food Packagingvi Pub. Co., Westport Connecticut.

Sacharow, S. 1966. A. Food Processing Trenos Thrust Packaging Materials Into the Sapce Age. Paper, Film Foil Conventer 40, No.5.p 58-61.

Sudarso, Y., 1997., Toksisitas Beberapa Senyawa Logam Berat Terhadap Siput Hydrobia sp., Limnotek Vol.5, No.1 Tahun 1997., Hal 75-79. Supranto, J., 1992., Tekhnik Sampling., Rineka Cipta., Jakarta

Underwood,A.L. Analisis Kimia Kuantitatif. Edisi Keenam. PT Erlangga. 421,425,427. www.wikipedia.org/wiki/Dagin g_kornet., Daging Kornet., diakses 01-03-2011.

www.pkpu.or.id/newsx.php., Suryanto., 2007., Daging Kornet., diakses 01-03-2011. 